\title{
Relaxation of the Lower Frit Loading Constraint for DWPF Process Control
}

by

K. G. Brown

Westinghouse Savannah River Company

Savannah River Site

Aiken, South Carolina 29808

DOE Contract No. DE-AC09-96SR18500

This paper was prepared in connection with work done under the above contract number with the U.S.

Department of Energy. By acceptance of this paper, the publisher and/or recipient acknowledges the U.S.

Government's right to retain a nonexclusive, royalty-free license in and to any copyright covering this paper, along with the right to reproduce and to authorize others to reproduce all or part of the copyrighted paper. 


\section{DISCLAIMER}

This report was prepared as an account of work sponsored by an agency of the United States Government. Neither the United States Government nor any agency thereof, nor any of their employees, makes any warranty, express or implied, or assumes any legal liability or responsibility for the accuracy, completeness, or usefulness of any information, apparatus, product or process disclosed, or represents that its use would not infringe privately owned rights. Reference herein to any specific commercial product, process or service by trade name, trademark, manufacturer, or otherwise does not necessarily constitute or imply its endorsement, recommendation, or favoring by the United States Government or any agency thereof. The views and opinions of authors expressed herein do not necessarily state or reflect those of the United States Government or any agency thereof.

This report has been reproduced directly from the best available copy.

Available for sale to the public, in paper, from: U.S. Department of Commerce, National Technical Information Service, 5285 Port Royal Road, Springfield, VA 22161

phone: (800) 553-6847

fax: (703) 605-6900

email: orders@ntis.fedworld.gov

online ordering: http://www.ntis.gov/ordering.htm

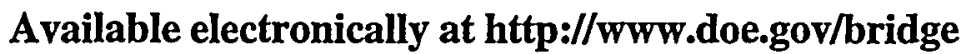

Available for a processing fee to U.S. Department of Energy and its contractors, in paper, from: U.S. Department of Energy, Office of Scientific and Technical Information, P.O. Box 62, Oak Ridge, TN 37831-0062

phone: (865)576-8401

fax: (865)576-5728

email: reports@adonis.osti.gov 


\section{DISCLAIMER}

Portions of this document may be illegible in electronic image products. Images are produced from the best available original document. 


\section{WESTINGHOUSE SAVANNAH RIVER COMPANY INTEROFFICE MEMORANDUM}
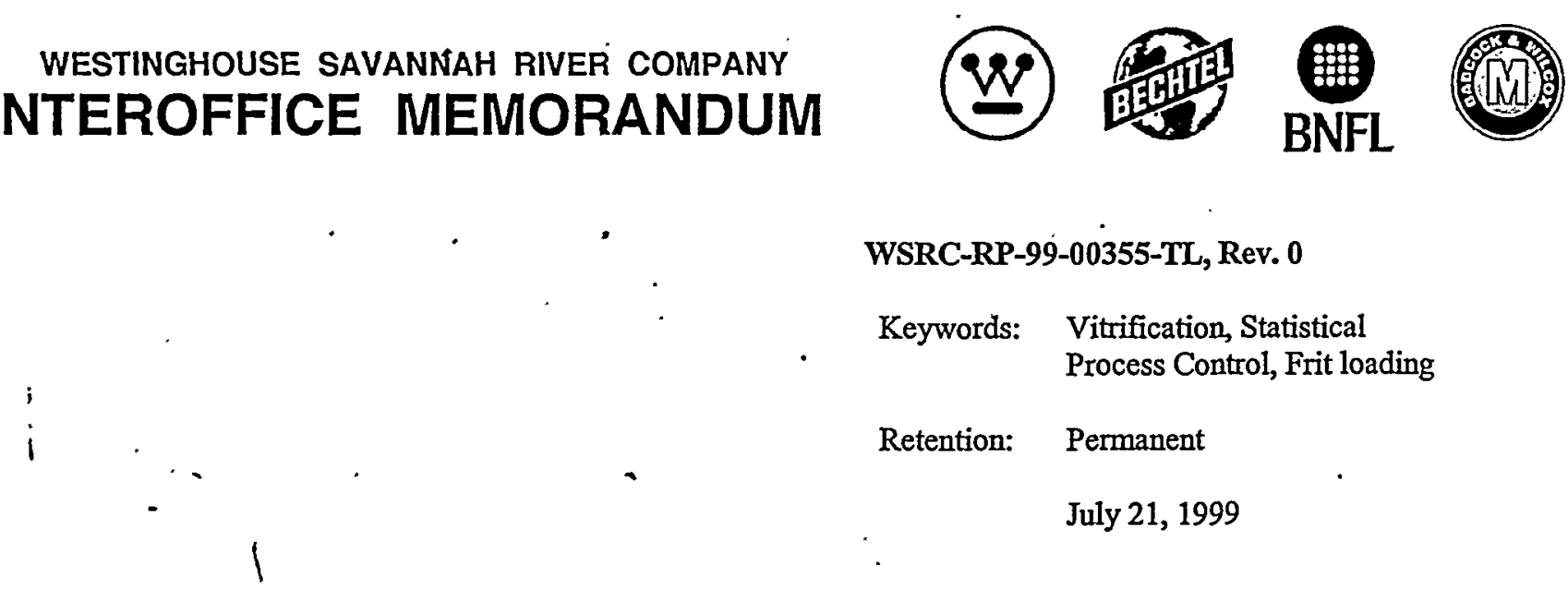

WSRC-RP-99-00355-TL, Rev. 0

Keywords: Vitrification, Statistical Process Control, Frit loading

Retention: Permanent

July 21,1999

M. N. BROSEE, PROGRAM MANAGER

WASTE DISPOSITION

Attention: W. D. Kerley, 704-S

Task Initiator: J.E. Occhipinti, 704-27S

\section{RELAXATION OF THE LOWER FRIT LOADING CONSTRAINT FOR DWPF PROCESS CONTROL (U)}

The attached document details an evaluation of the continued applicability of the low frit constraint for DWPF Slurry Mix Evaporator (SME) acceptability determinations. The conclusion of this evaluation is as follows:

The lower frit loading constraint carr be omitted as long as the $\mathrm{Al}_{2} \mathrm{O}_{3}$ concentration is greater than $4.43 \mathrm{wt} \%$ in glass and all other process and product constraints are applied as described in pertinent technical baseline documents.

This conclusion is applicable for all DWPF glasses, however, it is recommended that this be tested for each new macrobatch that will be immobilized in DWPF as part of the required variability study. If you have any questions regarding the attached report, please contact K.G. Brown (7-7799).

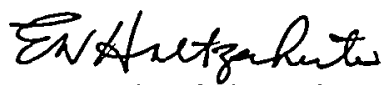

E. W. Holtzscheiter, Manager

SRTC - Immobilization Technology Section 
WSRC-RP-99-00355, Revision 0

i

RELAXATION OF THE LOWER FRIT LOADING CONSTRAINT FOR DWPF PROCESS CONTROL (U)

K. G. Brown

Westinghouse Savannah River Company

Savannah River Stte

Alken, SC 29808

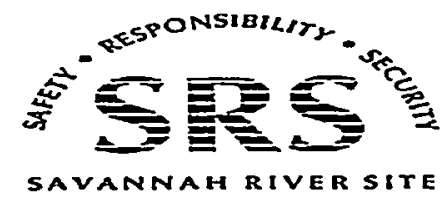

PREPARED FOR THE U.S. DEPARTMENT OF ENERGY UNDER CONTRACT NO. DE-ACO9-96SR18500 


\section{DISCLAIMER}

This report was prepared by Westinghouse Savannah River Company (WSRC) for the United States Department of Energy under Contract No. DE-AC0996SR18500 and is an account of work performed under that contract. Neither the United States Department of Ehergy, not WSRC, nor any of their employees makes any warranty, expresses or implied, assumes any legal liability or responsibility for accuracy, completeness, or usefulness, of any information, apparatus, or product or process disclosed herein or represents that its use will not infringe privately owned rights. Reference herein to any specific commercial product, process, or service by trademark, name, manufacturer or otherwise does not necessarily constitute or imply endorsement, recommendation, or favoring of same by WSRC or by, the United States Government or any agency thereof. The views and opinions of the authors expressed herein do not necessarily state or reflect those of the United States Government or any agency thereof. 
Keywords: Vitrification, Statistical Process Control, Frit loading

Retention: Permanent

\section{RELAXATION OF THE LOWER FRIT LOADING CONSTRAINT FOR DWPF PROCESS CONTROL (U)}

K. G. Brown

Publication Date: May 6, 1999

Westinghouse Savanalh Rtver Company

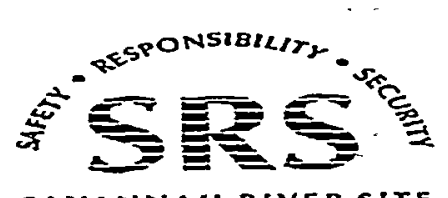

PREPARED EOR TTE U.S. DERARTMENT OR ENERGY UNDER CONTRACT NO. DE-AC09-96SR1850D 


\section{Approvals}

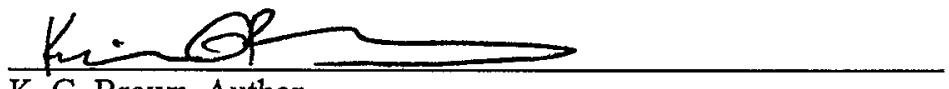

K. G. Brown, Author

\section{Whmas B Edwande}

T. B. Edwards, Technical Reviewer

\section{Caval M lanten}

C. M. Jantzen, Techngcal Revigrer

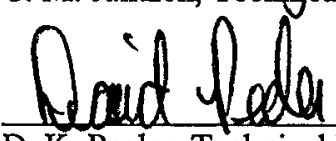

D. K. Peeler, Technical Reviewer

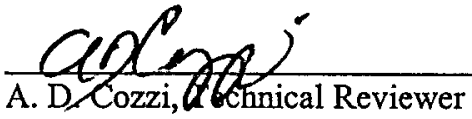

S\&Mana

S. L. Marra, Supervisor

Process Chemistry and Control

\section{Entbetzachecta}

E. W. Holtzscheiter, Manager and Authorized Derivative Classifier Immobilization Technology Section

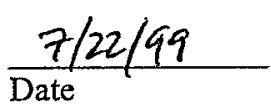

\section{$7 / 23 / 99$}

Date
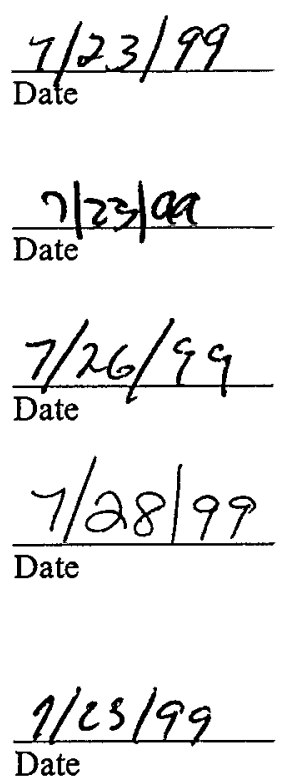


\title{
EXECUTIVE SUMMARY
}

The lower limit on the frit loading parameter, when measurement uncertainty is introduced, has restricted DWPF performance; therefore, any defensible relaxation or omission of this constraint should correspondingly increase DWPF waste loading and efficiency. Limits on the frit loading parameter were found necessary to assure that the homogeneity constraint would be applied to appropriate compositions. The homogeneity constraint, in turn, was needed to ensure that there was little possibility of producing phase separated glasses in DWPF since the current durability model, which relates durability (which cannot be measured in situ) to composition which can be determined, is applicable to homogeneous glasses. Phase separated glasses can leach differently than their homogeneous counterparts in a fashion that is not predictable. Thus the current waste acceptance specification for DWPF-that glass produced be demonstrably more durable than that of the Environmental Assessment (EA) glass based upon the Product Consistency Test (PCT)-has been translated into numerous constraints on composition.

\begin{abstract}
There are currently four general sets of constraints (not associated with waste solubility) that pertain to assuring acceptably durable glass is produced in DWPF: high and low frit loading, minimum $\mathrm{Al}_{2} \mathrm{O}_{3}$, homogeneity, and $\mathrm{B}, \mathrm{Li}$, and Na durability via the PCT. Since the data used to define the homogeneity constraint and durability model were not obtained from designed experiments, the high and low frit and $\mathrm{Al}_{2} \mathrm{O}_{3}$ constraints were necessary to assure that the homogeneity constraint and durability model pertained to the glass composition in question. The homogeneity constraint assures that the durability model will only be applied to homogeneous glasses. These constraints were developed from the best information available before DWPF began radioactive operations; however, there have been concerns that these constraints may be overly conservative or redundant.
\end{abstract}

There is an on-going effort to examine the aforementioned constraints related to durability to either remove any gross conservatism or redundancy. For example, it was determined from a preponderance of data that as long as the $\mathrm{Al}_{2} \mathrm{O}_{3}$ concentration was greater than $4 \mathrm{wt} \%$ in glass (or $\mathrm{Al}_{2} \mathrm{O}_{3} \geq 3 \mathrm{wt} \%$ and $(\mathrm{Cs}, \mathrm{K}, \mathrm{Li}, \mathrm{Na})_{2} \mathrm{O} \leq 19.3 \mathrm{wt} \%$ ), that the measurement acceptance requirement for the homogeneity constraint could be relaxed for DWPF glasses produced from Tank 42 Sludge (i.e., Macrobatch 2). This assertion was confirmed using data obtained from designed experiments. Since the lower frit loading constraint is now impacting DWPF operation, this constraint is the next to be examined in súch detail.

An earlier study indicated that the lower frit loading constraint could not be relaxed or omitted based upon purely mathematical or statistical reasoning. However, as described previously there have been occasions when certain requirements on a constraint have been relaxed based upon the current state of knowledge of DWPF glass chemistry when supported by experimental evidence. In a similar vein, the primary conclusion drawn from this examination of the lower frit loading constraint in light of all other DWPF process and product constraints is that the lower frit loading constraint can be omitted as long as the $\mathrm{Al}_{2} \mathrm{O}_{3}$ concentration is greater than $4.43 \mathrm{wt} \%$ in glass and all other process and product constraints are applied as described in pertinent technical baseline documents.

In other words, based upon glass chemistry knowledge and supported by experimental evidence, there appears to be no additional risk of unknowingly producing phase separated waste glasses in DWPF if the lower frit loading constraint is omitted-provided that the minimum $\mathrm{Al}_{2} \mathrm{O}_{3}$ limit is increased to $4.43 \mathrm{wt} \%$ in glass and all other constraints are applied as described in pertinent technical baseline documents. As a matter of fact, knowledge and experimental data indicate that DWPF glasses will be more likely to phase separate if the proportion of frit in the glass increases. Furthermore, the acceptance changes in applying the lower frit loading constraint pertain to all expected DWPF glasses, not just those for glasses produced from Tank 42 Sludge. However, it is recommended that these assertions be tested for each new macrobatch that will be immobilized in DWPF as part of required variability testing. 
INTRODUCTION

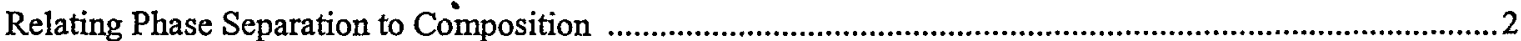

Examining the Frit Loading Constraints for DWPF Macrobatch 2 Operation ...................................................5

The Effect of $\mathrm{Al}_{2} \mathrm{O}_{3}$ on Glass Durability and Phase Separation ..........................................................................

GLASS CHEMISTRY PRINCIPLES AS THEY RELATE TO FRIT LOADING ......................................8

Lack of Analogy to Conservation or "Sum of Oxides" Constraints.................................................................. 8

Analogy to Relaxation of Homogeneity MAR Requirement for Tank 42 (or Batch 1B) Sludge .....................9

CONCLUSIŌNS AND RECOMMENDATIŌNS

REFERENCES

\section{LIST OF ILLUSTRATIONS}

1 The Constraints Related to DWPF Durability Prediction and Acceptance 2

2 The SRS glass discriminant function information is shown for the set of 110 THERMO model glasses with observed phase characteristics via electron microscopy .4

3 The relationship between wt $\% \mathrm{Al}_{2} \mathrm{O}_{3}$ in glass and $\mathrm{wt} \%(\mathrm{Cs}, \mathrm{K}, \mathrm{Li}, \mathrm{Na})_{2} \mathrm{O}$ in glass for all available glasses. The normalized boron releases for glasses with durabilities in the proximity of that for the EA glass are shown.

4 Boron durability versus composition for seven liquidus temperature study glasses exhibiting low frit loading. Model data are shown and computed frit loading values are provided. 


\section{INTRODUCTION}

The lower limit on the frit loading parameter when measurement uncertainty is introduced has impacted DWPF performance during immobilization of Tank 42 Sludge; therefore, any defensible relaxation or omission of this constraint should correspondingly increase DWPF waste loading and efficiency. Waste loading should be increased because the addition of frit is the current remedy for exceeding the lower frit loading constraint. For example, frit was added to DWPF SME Batches 94, 97 and 98 to remedy these batches for low frit loading. Attempts were also made to add frit in addition to the optimum computed to assure the lower frit loading çonstraint would be satisfied; however, approximately half of the SME Batches produced after Batch 98 have violated the lower frit loading constraint. If the DWPF batches did not have to be remediated and additional frit added because of the lower frit loading limit, then both the performance of the DWPF process and the waste loading in the glass produced would be increased.

Before determining whether or not the lower frit loading limit can be relaxed or omitted, the origin of this and the other constraints related to durability prediction must be examined. The lower frit loading constraint results from the need to make highly durable glass in DWPF. It is required that DWPF demonstrate that the glass produced would have durability that is at least two standard deviations greater than that of the Environmental Assessment (EA) glass [1]. Glass durability cannot be measured in situ; it must be predicted from composition which can be measured. Fortunately, the leaching characteristics of homogeneous waste glasses is strongly related to the total molar free energy of the constituent species [2]. Thus the waste acceptance specification has been translated into a requirement that the total molar free energy associated with the glass composition that would be produced from a DWPF melter feed batch be less than that of the EA glass accounting for both prediction uncertainty (including bias) and measurement uncertainty to a confidence level of 95\% [3]. However, it was discovered during Integrated DWPF Melter System (IDMS) testing that, under certain conditions, DWPF glasses were prone to phase separate resulting in glasses that had noticeably unpredictable and, at times, unacceptable leaching behavior.

Phase separation is the growth of two or more non-crystalline glassy phases each of which possesses a different composition than that of the overall melt [4]. Such phase separation generally takes the form of immiscible liquid phases which differ not only in chemical composition, but also in density and surface tension. Factors such as the relative densities and viscosities of the resulting liquid phases, their interphase surface energies, and the melt conditions determine the behavior and degree of separation of the resulting glass phases [5]. Furthermore, if the composition of one of the phases in contact with the leaching medium is such that the phase is highly leachable (relative to the overall glass composition), then the durability of the glass produced will not only be unpredictable from current information; the glass may leach more than the EA glass which is the benchmark for acceptable glass durability [6]. Thus a restriction denoted the homogeneity constraint was formulated in composition space to ensure that there was very little possibility of this scenario occurring in DWPF $[2,7]$.

Thus the homogeneity constraint was necessary to ensure that there was little chance of producing phase separated glasses in DWPF since the durability model, which relates the normalized release to composition, is applicable to homogeneous glasses. The homogeneity constraint defines phase separation in waste glasses in terms of the less dense (or "lighter weight") constituents and the more dense (or "heavier weight") constituents. The more dense constituents are oxides primarily found in sludge, and the contribution from these oxides has been, perhaps confusingly, denoted "sludge loading." Similarly, the less dense constituents are oxides primarily found in the glass forming frit; therefore, their contribution was designated as the "frit loading," which is not synonymous with the relative contribution of the frit in glass. ${ }^{2}$

1 The parameter in the homogeneity constraint that has been denoted as "sludge loading," which is comprised of only a selected subset (i.e., $\mathrm{Al}_{2} \mathrm{O}_{3}, \mathrm{CaO}, \mathrm{Ce}_{2} \mathrm{O}_{3}, \mathrm{Fe}_{2} \mathrm{O}_{3}, \mathrm{La}_{2} \mathrm{O}_{3}, \mathrm{MoO}_{3}$, and $\mathrm{Y}_{2} \mathrm{O}_{3}$ ) of sludge oxides, should not be confused with the relative fraction of total sludge oxides in glass which is normally referred to as sludge loading. This distinction will be emphasized in this report to avoid confusion.

2 For example, Frits 200 and 202 contain a significant fraction of $\mathrm{MgO}$ which is not included in the frit loading definition. Other frits have contained oxides such as $\mathrm{TiO}_{2}$ and $\mathrm{ZrO}_{2}$ which are also not included in the frit loading definition. 
The data used to define the homogeneity constraint were not obtained from designed experiments. Thus it could not be determined whether the two phase liquid-liquid immiscibility boundaries in this idealized frit-sludge composition space had been adequately defined. Limits were thus necessary to restrict the locus of glass compositions over which the homogeneity constraint was applicable. Due to the complexity of the idealized sludge loading definition (including incorporating a number of oxides not appearing in significant concentrations in DWPF glasses), it was deemed unsatisfactory to impose a constraint based upon this parameter. Instead a domain restriction was imposed upon the frit loading parameter since this term was easily defined and reasonable, and the glass fractions represented by the sludge and frit loading parameters are nearly çomplementary for DWPF glasses.

Thus as illustrated in Figure 1, there are currently four general sets of constraints (not associated with waste solubility) that are necessary to assure that acceptably durable glass is produced in DWPF: high and low frit loading, minimum $\mathrm{Al}_{2} \mathrm{O}_{3}$, homogeneity, and $\mathrm{B}, \mathrm{Li}$, and $\mathrm{Na}$ durability. Since the data used to define the homogeneity condtraint were not obtained from designed experiments, the frit loading constraints were necessary to assure that the homogeneity constraint would only be applied to appropriate glass compositions. The constraint on minimum $\mathrm{Al}_{2} \mathrm{O}_{3}$ in glass was needed to assure that glasses were in a composition region where the durability model would apply [3]. The homogeneity constraint assures that the current durability model will only be applied to homogeneous glasses. Once these constraints have been satisfied, then the $\mathrm{B}, \mathrm{Li}$, and $\mathrm{Na}$ normalized releases can be estimated and tested against the EA glass release for acceptability. These constraints were developed from the best information available before DWPF began radioactive operations; however, there have been concerns that these constraints related to durability prediction may be overly conservative and/or redundant.

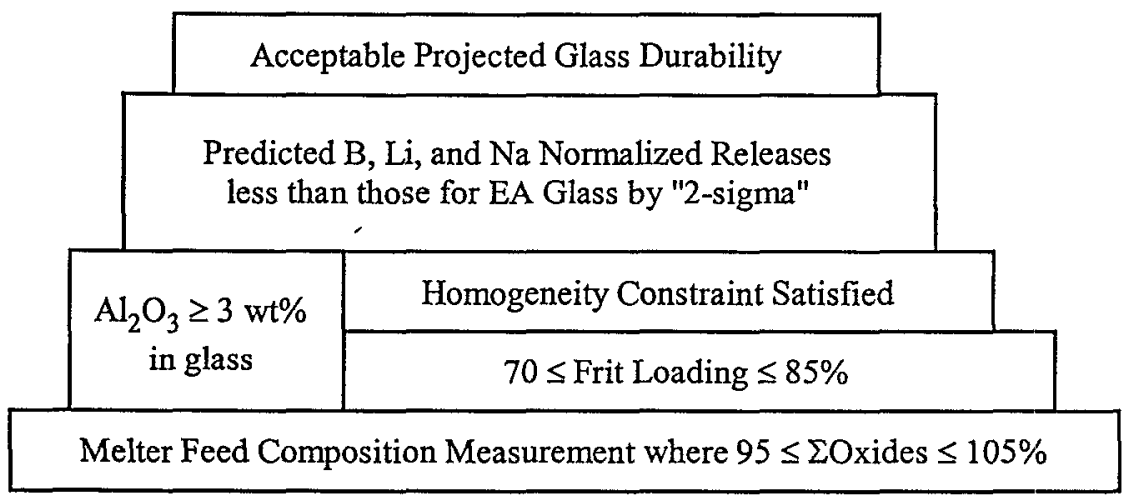

Figure 1. The Constraints Related to DWPF Durability Prediction and Acceptance

There has been an on-going effort to examine the constraints related to durability prediction to either remove any gross conservatism or redundancy. For example, it was previously determined from a preponderance of historic information that as long as the $\mathrm{Al}_{2} \mathrm{O}_{3}$ concentration was greater than approximately $4 \mathrm{wt} \%$ in glass (or $\mathrm{Al}_{2} \mathrm{O}_{3} \geq 3 \mathrm{wt} \%$ and $\left.(\mathrm{Cs}, \mathrm{K}, \mathrm{Li}, \mathrm{Na})_{2} \mathrm{O} \leq 19.3 \mathrm{wt} \%\right)$, that the measurement acceptance requirement for the homogeneity constraint could be relaxed for DWPF glasses produced from Tank 42 Sludge [8]. This assertion was confirmed using data obtained from designed experiments. Since the lower frit loading constraint has impacted DWPF performance, this constraint is the next to be examined in such detail.

\section{Relating Phase Separation to Composition}

The homogeneity constraint is necessary to ensure that there is little chance of producing phase separated glasses in DWPF since the durability model, which relates the normalized release to composition, is applicable to homogeneous glasses. The homogeneity constraint defines phase separation in waste glasses in terms of the less dense (or "lighter weight") constituents and the more dense (or "heavier weight") constituents. The more dense constituents are oxides primarily found in sludge, and the contribution from these oxides has been denoted "sludge loading." This "sludge loading" parameter should not be confused with the relative fraction of total sludge oxides in glass. The less dense constituents are oxides (i.e., $\mathrm{Cs}_{2} \mathrm{O}, \mathrm{K}_{2} \mathrm{O}, \mathrm{Li}_{2} \mathrm{O}, \mathrm{Na}_{2} \mathrm{O}, \mathrm{B}_{2} \mathrm{O}_{3}$, and 
$\mathrm{SiO}_{2}$ ) primarily found in the glass forming frit; therefore, their contribution was designated as the "frit loading," which is not synonymous with the relative contribution of the frit in glass. If the parameter $\xi_{\text {oxide }}$ indicates the true mass percentage of an oxide in glass, then the true sludge, $\Sigma_{\mathrm{s}}$, and frit loading, $\Sigma_{\mathrm{f}}$, parameters are defined as:

$$
\begin{aligned}
& \Sigma_{\mathrm{s}} \equiv \xi_{\mathrm{Al}_{2} \mathrm{O}_{3}}+\xi_{\mathrm{CaO}}+\xi_{\mathrm{Ce}_{2} \mathrm{O}_{3}}+\xi_{\mathrm{Fe}_{2} \mathrm{O}_{3}}+\xi_{\mathrm{La}_{2} \mathrm{O}_{3}}+\xi_{\mathrm{MoO}_{3}}+\xi_{\mathrm{Nd}_{2} \mathrm{O}_{3}}+\xi_{\mathrm{Y}_{2} \mathrm{O}_{3}} \\
& \Sigma_{\mathrm{f}} \equiv \xi_{\mathrm{Cs}_{2} \mathrm{O}}+\xi_{\mathrm{K}_{2} \mathrm{O}}+\xi_{\mathrm{Li}_{2} \mathrm{O}}+\xi_{\mathrm{Na}_{2} \mathrm{O}}+\xi_{\mathrm{B}_{2} \mathrm{O}_{3}}+\xi_{\mathrm{SiO}_{2}}
\end{aligned}
$$

A database consisting of 110 glasses which had "known" phase characteristics and compositions was previously compiled from historic DWPF information [2]. Of these glasses, 88 were characterized as homogeneous and 22 were characterized as phase separated. Concentrations measured by Corning Engineering Laboratory Services (CELS) or bias-corrected to CELS standards were used to estimate $\Sigma_{\mathrm{s}}$ and $\Sigma_{\mathrm{f}}$ for these glasses since CELS measurement errors were likely negligible when appropriately compared to the currently indeterminate errors in properly classifying phase separated versus homogeneous glasses $[3,7]$.

Figure 2 illustrates the distribution of the 110 "known" glasses in the composition space defined by the sludge and frit loading parameters defined previously. In this particular contrived composition space, there is an apparent distinction between the homogeneous $(\boldsymbol{0})$ and phase separated ( $\boldsymbol{(})$ populations as indicated by the ellipsoids. However, the ellipsoidal appearance of the distributions is merely an artifact of the glass compositions considered. For example, if the glass compositions had been generated using an optimized, extreme vertices-mixture design, the distributions would likely have resembled trapezoids instead of ellipses. However, because the distributions happened to resemble ellipses, a mathematical description based upon a discriminant analysis was used to define a constraint that discriminated between those compositions likely or not likely to be homogeneous [7] in the contrived composition space. For the glasses represented in Figure 2, if the composition satisfied the following constraint:

$$
-5.6478 \Sigma_{s}-1.6035 \Sigma_{f}+210.9203 \leq 0,
$$

then the glass would likely be homogeneous and the durability model would be applicable. ${ }^{3}$

However, since the glasses were not obtained from statistically designed studies, there was a need to assure that the homogeneity constraint represented by Equation 1 would be applied to only those glasses from the same general composition domain as those used to develop the constraint. The desired solution [7] would have been to place domain restrictions on the sludge loading parameter, $\Sigma_{s}$, for the glass in question. Unfortunately due to the complexity of the sludge loading definition (including incorporating a number of cations not appearing in significant concentrations in DWPF glasses), it was deemed unsatisfactory to impose a constraint based upon the $\Sigma_{s}$ parameter. Instead a domain restriction was imposed upon the frit loading parameter, $\Sigma_{f}$, for a glass since this term was easily defined and reasonable, and the fact that these parameters are nearly complementary for DWPF glasses [7]. Thus the restriction: $70 \leq \Sigma_{\mathrm{f}} \leq 85 \%$ was placed on DWPF glasses to assure that the constraint in Equation 1 would be legitimately applied (since this is the range of the frit loading parameter considered in Figure 2) [7].

It is the lower limit on frit loading (i.e., $70 \leq \Sigma_{\mathrm{f}}$ )-when measurement uncertainty is introduced-that currently impacts DWPF operational efficiency for DWPF Macrobatch 2. It is desired to determine if the measurement uncertainty requirement for the lower frit loading constraint can be relaxed-as it was for the homogeneity constraint for DWPF Macrobatch 2 operation [8]—or, ultimately, omitted in a defensible manner and the available DWPF operating region and efficiency correspondingly increased.

3 As noted previously, a separate constraint, $\mathrm{Al}_{2} \mathrm{O}_{3} \geq 3 \mathrm{wt} \%$ in glass, was needed to assure that the glasses produced would be in a composition region where the durability model is applicable [3]. 


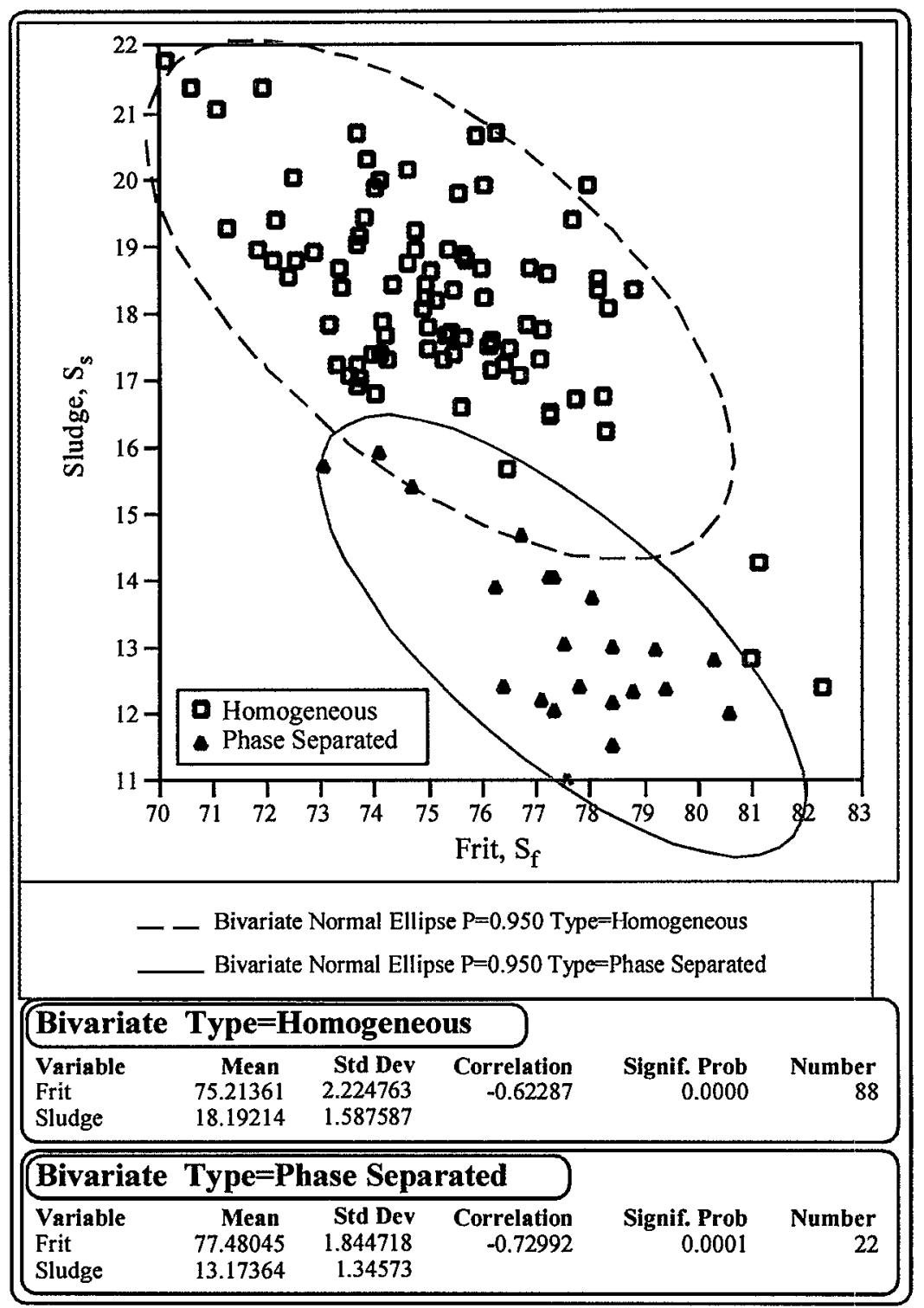

Figure 2. The SRS glass discriminant function information is shown for the set of 110 THERMO model glasses with "known" phase characteristics [7].

\section{Examining the Frit Loading Constraints for DWPF Macrobatch 2 Operation}

Historically, it had been hoped that the frit loading constraints might be discovered to be redundant when all other processing and product constraints (e.g., durability, liquidus temperature, melt viscosity, etc.) are imposed to determine acceptance. For example, it can be shown that the lower frit loading and either the liquidus temperature or the homogeneity constraints can be redundant under certain DWPF processing conditions [9]. In general, however, the lower frit loading will not be redundant with any constraint or set of constraints for DWPF Macrobatch 2 material [9]. Thus there is no simple, mathematical argument to omit, or even relax, the lower frit loading constraint.

Since there is no straightforward mathematical argument for frit loading relaxation, it was hoped that apparent violations of the lower frit loading constraint for DWPF Macrobatch 2 operation might be due to solely measurement uncertainty issues. For example, it can be shown that $\Sigma_{\mathrm{f}}$ must be greater than $70 \%$ (i.e., a glass 
must satisfy the lower frit loading constraint) if the true total oxide contribution from sludge to glass-not the sludge loading parameter-is less than $26.7 \%$ (for sludge-only operation using Frit 200 [9]). Since initial testing of the Macrobatch 2 sludge material indicated that the total oxide contribution from sludge to glass might be as high as approximately $26 \%$ [10], the sludge loading of the material produced by DWPF during Macrobatch 2 was examined. The total oxide contributions from sludge to glass-again not the sludge loading parametersfor the Macrobatch 2 SME batches were consistently and significantly greater than $26.7 \%$ meaning that fortunately DWPF was able to obtain higher total oxide contributions from sludge to glass than initial tests indicated. It was determined that the lower frit loading constraint could not be omitted, or even relaxed, based upon this or any other purely mathematical or statistical reasoning [9].

However, there have been examples where the measurement uncertainty requirements for DWPF process control constraints have been relaxed for other than strictly mathematical or statistical reasons. A strict application of measurement uncertainty was not required for the $\Sigma$ Oxides constraints since [3]:

"[t]he conservation, or 'sum of oxides' [or $\Sigma$ Oxides] specification was defined by the principal investigator to assure that the laboratory providing the composition analyses was under control... This specification is a bound on laboratory analyses based upon tolerable errors when attempting to predict durability from glass composition. Thus no additional [measurement] error must be incorporated when applying this specification to DWPF control analyses." .

The reasoning for not requiring the introduction of measurement uncertainty for the $\Sigma$ Oxides constraint was based upon expert knowledge of the behavior of the glass dissolution and analysis phenomena [2,11] - not strictly on mathematical or statistical grounds.

\section{The Effect of $\mathrm{Al}_{2} \mathrm{O}_{3}$ on Glass Durability and Phase Separation}

For DWPF Macrobatch 2 operation, the measurement uncertainty requirement was relaxed for the homogeneity constraint based upon historical evidence and, again, expert knowledge [8]. As illustrated in Figure 3, the composition and durability measurements for well over a thousand waste glasses ${ }^{4}$ were examined, and it was discovered that either 1) increasing the minimum $\mathrm{Al}_{2} \mathrm{O}_{3}$ to $4 \mathrm{wt} \%$ or 2) imposing an additional constraint of $(\mathrm{Cs}, \mathrm{K}, \mathrm{Li}, \mathrm{Na})_{2} \mathrm{O} \geq 19.3 \mathrm{wt} \%$ in glass appeared to assure that Macrobatch 2 glasses would likely be significantly more durable than the EA glass [8]. Of all these glasses, there were only six that had normalized releases in the proximity of the EA glass value while violating either of the two constraints enumerated above. However, these six glasses from the Hanford CVS [15] were either exceedingly high in $\mathrm{B}_{2} \mathrm{O}_{3}(\geq 19.6 \mathrm{wt} \%$ in glass) or low in $\mathrm{Fe}_{2} \mathrm{O}_{3}$ ( $\leq 2.5 \mathrm{wt} \%$ in glass). Thus these six fall well outside the feasible range of glasses expected during Macrobatch 2 processing and do not pose problems for Tank 42 Sludge immobilization using either of the above two constraints.

These results do indicate that if DWPF is ever required to produce glasses with much higher $\mathrm{B}_{2} \mathrm{O}_{3}$ concentrations than are currently expected, that the effects of $\mathrm{B}_{2} \mathrm{O}_{3}$ on phase separation and durability will have to be examined in much greater detail. (A similar case can also be made for any DWPF glasses that have very low $\mathrm{Fe}_{2} \mathrm{O}_{3}$ concentrations.) However, discussion of the potential impacts of $\mathrm{B}_{2} \mathrm{O}_{3}$ on phase separation and durability are outside the scope of this report as there is no current plausible scenario for producing DWPF glasses high enough in $\mathrm{B}_{2} \mathrm{O}_{3}$ to be problematic.

4 These glasses represent all the data used for THERMO model development and validation [2], the sludgeonly glasses from the Tank 51 variability study $[12,13]$, the two pour stream samples from DWPF macrobatch 1 [14], the PNNL Compositional Variation Study (CVS) glasses [15], and the glasses from the Tank 42 variability study [8]. 


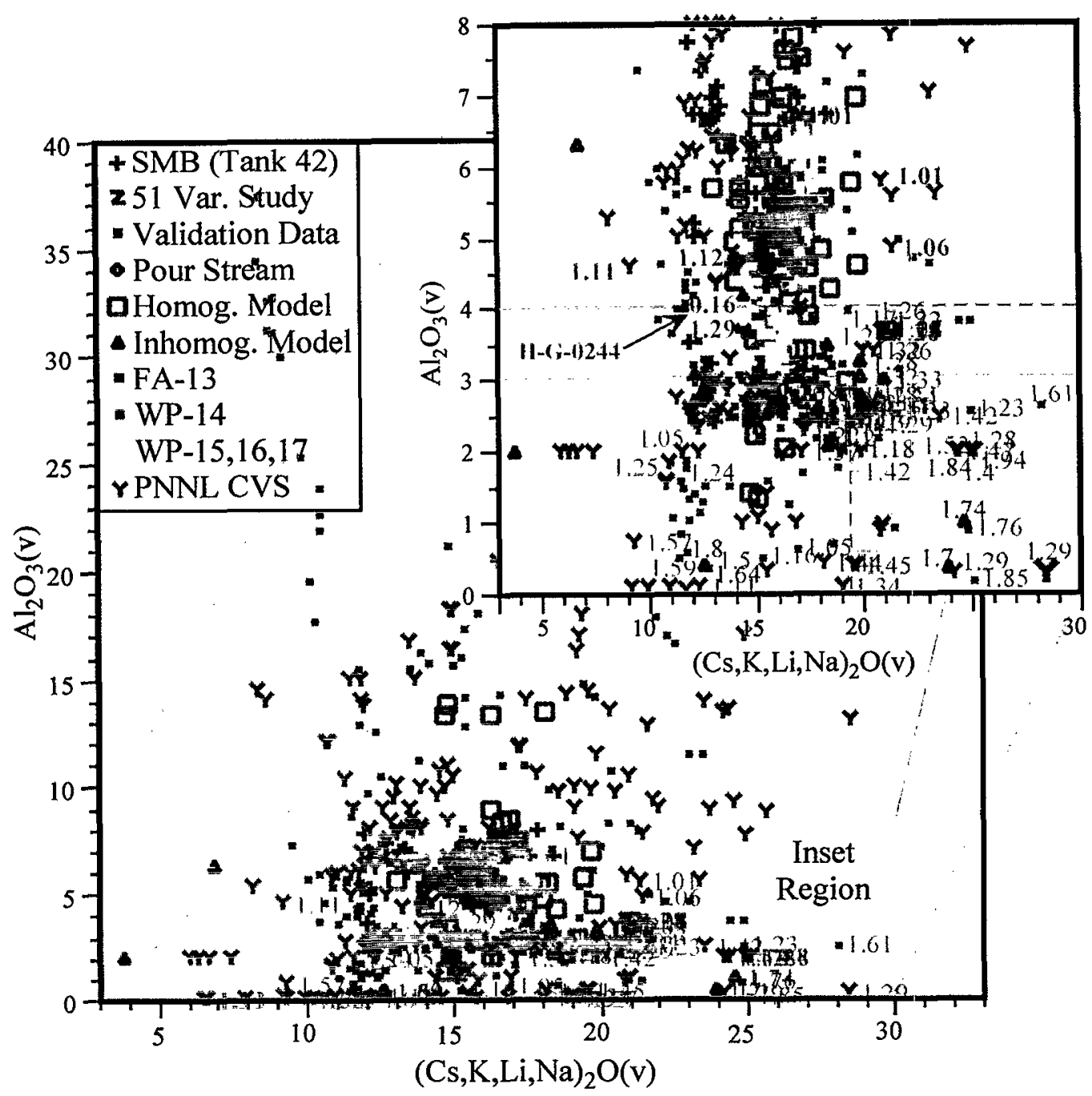

Figure 3. The relationship between $w t \% \mathrm{Al}_{2} \mathrm{O}_{3}$ in glass and $w t \%(\mathrm{Cs}, \mathrm{K}, \mathrm{Li}, \mathrm{Na})_{2} \mathrm{O}$ in glass for all available glasses. The normalized boron releases for glasses with durabilities in the proximity of that for the EA glass are shown.

There is one additional glass of interest to the examination of durability and phase separation as possible functions of the $\mathrm{Al}_{2} \mathrm{O}_{3}$ and $(\mathrm{Cs}, \mathrm{K}, \mathrm{Li}, \mathrm{Na})_{2} \mathrm{O}$ concentrations in glass: Hanford Glass $\mathrm{H}-\mathrm{G}-0244$. This particular glass, which is highlighted in Figure 3, was found to be phase separated by TEM even though it possessed a measured $\mathrm{Al}_{2} \mathrm{O}_{3}$ concentration of $4.17 \mathrm{wt} \%$ in glass. However, it should be noted that this measured concentration for $\mathrm{H}-\mathrm{G}-0244$ was below the limit of $4.36 \mathrm{wt} \% \mathrm{Al}_{2} \mathrm{O}_{3}$ in glass recommended in Reference 8 when measurement uncertainty is introduced. This glass also had a measured $\mathrm{B}_{2} \mathrm{O}_{3}$ concentration of $9.1 \mathrm{wt} \%$ in glass which is considerably greater than the maximum (i.e., $\mathrm{B}_{2} \mathrm{O}_{3} \leq 7.5 \mathrm{wt} \%$ in glass) expected for DWPF processing [16]. Furthermore, this glass did possess a normalized release approximately an order of magnitude less than that of the EA glass and, thus, does not appear to impact the conclusions from the homogeneity relaxation effort [8]. However, since few of the glasses represented in Figure 3 were collected from designed experiments, it will be recommended in this report that the minimum $\mathrm{Al}_{2} \mathrm{O}_{3}$ concentration be raised from 4.36 to $4.43 \mathrm{wt} \% 5$ in glass

5 The value of 4.43 is obtained when the relative percent standard deviation of $5.1 \%$ (and 21 degrees of

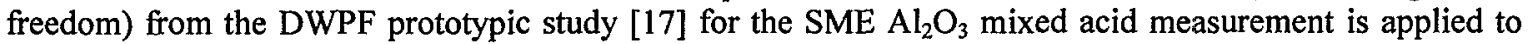
the mean of the two composition analyses for the H-G-0244. These analyses were performed by ADS; however, this is the best measurement information currently available. 
for DWPF operation because this limit will be based upon the highest measured alumina concentration for which phase separated glasses have been observed. This should help prevent both poorly durable as well as phase separated glasses from being produced in DWPF.

The relaxation of the homogeneity constraint for DWPF Macrobatch 2 was intended to help increase operational efficiency in DWPF since this constraint significantly affected Macrobatch 1 and was thought likely to impact the next macrobatch. Unfortunately, because of composition differences between Macrobatches 1 and 2 [9], relaxation of the homogeneity constraint did not significantly improve operational efficiency for Macrobatch 2 as the lower frit loading constraint was merely violated instead causing remediation of SME biatches to still be necessary at a much higher frequency than expected. Thus the anticipated efficiency increase was not realized for DWPF Macrobatch 2 operation when the measurement uncertainty requirement was relaxed for the homogeneity constraint. This "resulted in a detailed examination of the lower frit loading constraint. 


\section{GLASS CHEMISTRY PRINCÍPLES AS THEY RELATE TO FRIT LOADING}

A strict mathematical examination of the frit loading specification (in light of all other process and product constraints) does not allow for omission or even relaxation for DWPF Macrobatch 2 operation [9]. However, in the past, the measurement uncertainty requirements for selected process control constraints (e.g., $\Sigma$ Oxides in general and homogeneity for Macrobatch 2) have been relaxed based upon a solid foundation of both statistical and glass chemistry knowledge $[3,8]$. The treatment of these constraints will be investigated to see if the frit loading constraints can be relaxed based upon similar reasoning. However, this examination of the lower frit loading constraint is just an interim measure. Whether or not the lower frit loading constraint can be relaxed, the information obtained from this study will be used in conjunction with that collected since DWPF start-up in the dn-going reevaluation of those constraints (e.g., $\mathrm{Al}_{2} \mathrm{O}_{3}$, homogeneity, etc.) associated with durability prediction.

\section{Lack of Analogy to Conservation or "Sum of Oxides" Constraints 1}

As previously stated, the specification on the frit loading parameter (i.e., $70 \leq \Sigma_{\mathrm{f}} \leq 85 \%$ ) was deemed necessary to restrict application of the homogeneity constraint to only those glasses from a compositional domain similar to that used to derive the homogeneity constraint [7]. In this respect, the frit loading constraints resemble the specification on the conservation of measured oxide mass or $\Sigma$ Oxides (i.e., $95 \leq \Sigma$ Oxides $\leq 105 \%$ ) which is used primarily as a check on laboratory composition measurements necessary for durability prediction. Using this rationale, it was determined that no additional measurement acceptance requirement would have to be imposed upon the $\Sigma$ Oxides constraints for DWPF process control [3].

It will be difficult to make an analogous case that no measurement acceptance requirement should be imposed upon the frit loading constraints for DWPF process control. The frit loading specification is also meant to be a bound on necessary laboratory analyses, but in this case, based upon tolerable composition measurement errors when attempting to predict phase separation in new waste glass compositions. However, it must be recognized that the characterization of homogeneity is very different from that of durability. The durability of a homogeneous waste glass can be measured; it is a continuous variable that can be related to a rational, firstprinciples based function of composition [2]. On the other hand, the homogeneity of a glass is a categorical description of the nature of the phases comprising the glass that is scale dependent and difficult to definitively discern, especially for the techniques (i.e., Scanning and Transmission Electron Microscopy) used to examine the DWPF glasses. The relationship described by Equation 1 is merely a mathematical description of the discrimination (e.g., "Yes/No" relationship) obtained between the (categorical) homogeneous and phase separated populations in the contrived composition space illustrated in Figure 2. Equation 1 is not a firstprinciples based relationship relating a continuous variable (e.g., durability, viscosity, etc.) to a rational function of composition. Therefore, it is very difficult, if not impossible, to determine what errors would be tolerable for such a relationship as homogeneity; the analogy between $\Sigma$ Oxides and frit loading is thus lacking.

Furthermore, one other difference between these specifications is that the expectation for $\Sigma$ Oxides is towards the middle of the acceptance region (i.e., an error-free analysis of a glass composition including all correct oxide forms would equal $100 \%$ ); whereas, the expected value for the frit loading parameter (all other things being equal) depends upon the waste and frit compositions as well as the target total sludge oxides in glass. In other words, as analyses improve (or more samples are analyzed), the $\Sigma$ Oxides parameter will tend to approach the middle of its acceptance region (i.e., $95 \leq \Sigma$ Oxides $\leq 105 \%$ ); whereas, the frit loading parameter will merely approach its true value which is both composition and target dependent and might well fall outside its acceptable region of $70 \leq \Sigma_{\mathrm{f}} \leq 85 \%$. Thus the information pertaining to relaxation of the measurement acceptance requirement for the $\Sigma$ Oxides constraint will not allow the lower frit loading constraint to be relaxed in a similar fashion.

\section{Analogy to Relaxation of Homogeneity MAR Requirement for Tank 42 (or Batch 1B) Sludge}

As noted previously, there is one other constraint whose current DWPF process control implementation does not require the introduction of composition measurement uncertainty for acceptance determination: the homogeneity constraint for Tank 42 (or Batch 1B) Sludge [8]. All subsequent discussions of homogeneous versus phase separated glasses in this report are made assuming that a single cooling regime (i.e., quenching) is 
used. In general, amorphous phase separation, which cannot be measured in situ, must be avoided in DWPF glasses since such glasses can leach differently than their homogeneous counterparts in a fashion that cannot be predicted. The durability of phase separated waste glasses has been found to be unpredictable by any known first-principles based models [2]. Various relationships were investigated in an attempt to adequately discriminate between homogeneous and phase separated glasses in composition space [7] for DWPF process control. Based upon distributions in the $\left(\Sigma \mathrm{R}_{2} \mathrm{O}-\left(\mathrm{SiO}_{2}+\mathrm{Al}_{2} \mathrm{O}_{3}\right)-\mathrm{B}_{2} \mathrm{O}_{3}\right)$ ternary and $\Sigma \mathrm{R}_{2} \mathrm{O}-\mathrm{Al}_{2} \mathrm{O}_{3}-\mathrm{B}_{2} \mathrm{O}_{3}-\mathrm{Fe}_{2} \mathrm{O}_{3}$ quaternary composition spaces. and phase classifications determined from scanning and transmission electron microscopy, a relationship was discerned based on up to seven major and seven minor glass components that adequately distinguished the 22 phase separated from the 88 homogeneous waste glass compositions whose phase characteristics had been determined [7]. This relationship was described by Equation 1 and its dorresponding discrimination of the available data was illustrated in Figure 2.

Thus discrimination between the available homogeneous and phase separated glasses was adequately described in a composition space synthesized from two macro-components: 1) the oxide mass from all sources of alkali, boron, and silicon (or the less dense components) and 2) the oxide mass from selected sludge (or denser) components. Some sludge components (e.g., those for $\mathrm{Ni}, \mathrm{Mn}$, etc.) in significant concentrations were excluded from the sludge macro-component because they were found to be insignificant to the discrimination. Other, minor sludge constituents (e.g., Y, Mo, etc.) had significant influence on discrimination [7]. However, these influences may be misleading - and possibly specious - as few of the glasses examined, if any, were obtained from statistically designed experiments. Furthermore, they were outside the range of current DWPF operation. If it is discovered that glass durability cannot be directly related to composition (that is, without the need of such intermediaries as homogeneity and frit loading), such designed experiments will be needed to better define the sludge macro-component necessary to describe adequately all expected DWPF waste glasses.

Despite these concerns, the composition space described in Figure 2 appears to make intuitive sense because glass-in-glass phase separation normally forms as glasses of different densities (which are thus related to the mass-not molar-oxide fractions) separate out of the primary glass phase. Since most of the less dense or "lighter" components in DWPF waste glass come primarily from glass-forming frits, the parameter, $\Sigma_{\mathfrak{f}}$ in Equation 1 describing these less dense component concentrations was referred to as "ffit loading" or " $\Sigma$ Frit" (where $\Sigma$ Frit $\equiv \Sigma_{\mathrm{f}}$ ). The frit loading parameter should not be confused with the fraction of total frit in glass. Thus the domain restrictions that were necessary to restrict application of the homogeneity constraint to only appropriate glass compositions, which were defined based upon the $\Sigma$ Frit parameter [7], were referred to as the frit loading constraints. It is desired to relax the measurement uncertainty for (or omit altogether) the lower frit loading constraint without increasing the risk of producing phase separated and/or poorly durable waste glasses in DWPF.

However, before assessing any ramifications resulting from relaxing the lower frit loading constraint, the homogeneity constraint must be examined in greater detail. It is known that the relationship described in Figure 2 , whereby the phase separation is related to the sludge and frit loading parameters, does not provide the complete story. It has been demonstrated that the presence of sufficient $\mathrm{Al}_{2} \mathrm{O}_{3}$ profoundly mitigates amorphous phase separation in borosilicate glasses [18] - that is, in a manner not entirely described by the homogeneity discriminator found in Figure 2 [8]. For example, the addition of $\mathrm{Al}_{2} \mathrm{O}_{3}$ to a phase separated DWPF PUREXtype glass resulted not only in a homogeneous glass but also an order of magnitude reduction in the normalized boron release [2]. It was attempted to capture this behavior of $\mathrm{Al}_{2} \mathrm{O}_{3}$ by defining a separate limit on the minimum alumina concentration (i.e., $\mathrm{Al}_{2} \mathrm{O}_{3} \geq 3.0 \mathrm{wt} \%$ ) that must be present in DWPF glass to assure that durability would be predictable [3]. Furthermore, the preponderance of durability and composition data for waste glasses representative of those expected in DWPF indicates that it is most likely the combination of low $\mathrm{Al}_{2} \mathrm{O}_{3}$ (which allows, or perhaps promotes, phase separation) and high alkali concentrations (which indicates an exacerbated strong base-weak acid effect [2]) that results in poorly durable DWPF glasses ${ }^{6}$ [8]. These data also indicate that if the $\mathrm{Al}_{2} \mathrm{O}_{3}$ concentration is maintained above $4 \mathrm{wt} \%$ in glass that poorly durable glasses will likely not be produced at even much higher total alkali concentrations (e.g., up to $30 \% \Sigma \mathrm{R}_{2} \mathrm{O}$ in glass) [8]; furthermore, such DWPF glasses will tend to be predictable (by the current durability model [2]) since they are

6 In this report, "poorly durable" indicates normalized leach values approaching (or worse than) those obtained for the Environmental Assessment (EA) glass. See Figure 4 on page 11 for an illustration. 
not likely to undergo amorphous phase separation [8]. However, since few of these data were obtained from designed studies, it was necessary that the results from the required, designed variability study for Tank 42 sludge [19] confirm these assertions, which they did [8].

As part of the study to determine whether, the measurement uncertainty requirement for the homogeneity constraint could be relaxed, it was noted that the alkali sum, $\Sigma \mathrm{R}_{2} \mathrm{O}$, in concert with $\mathrm{Al}_{2} \mathrm{O}_{3}$ appeared to significantly impact durability; whereas, the $\mathrm{Al}_{2} \mathrm{O}_{3}$ concentration alone was a reliable indicator of phase separation for expected DWPF glass compositions [8]. However, there was insufficient evidence to redefine the phase separation discriminator solely in $\mathrm{Al}_{2} \mathrm{O}_{3}-\Sigma \mathrm{R}_{2} \mathrm{O}$ space (or to relate durability to composition, in general); this space appeared much more amenable to bounding poorly durable glass than allowing the prediction of phase separation. Additional such evidence, if obtained, may provide the vehicle necessary to relate durability directly to composition, foregoing the need to determine homogeneity (and thus to verify frit loading). A rigorous approach to assigning a confidence level will be necessary to make this approach viable for DWPF process control. Work is currently planned to examine the likelihood of using the $\mathrm{Al}_{2} \mathrm{O}_{3}-\Sigma \mathrm{R}_{2} \mathrm{O}$ composition space to either help reduce the number of constraints on DWPF durability prediction or directly relate durability to composition space.

Therefore, although the $\mathrm{Al}_{2} \mathrm{O}_{3}$ and $\Sigma \mathrm{R}_{2} \mathrm{O}$ concentrations appear to provide valuable insight into both phase separation and durability [8] for expected DWPF glass compositions [16], there appears to be no strong relationship between just the frit loading parameter and either the tendency for a DWPF glass to phase separate or be poorly durable. In fact there can be no fundamental relationship between just frit loading and either phase separation or durability; otherwise, the intended relaxation of the lower frit loading constraint would be untenable for DWPF process control. As illustrated in Figure 2, the projections of the homogeneous and phase separated glass compositions onto the frit loading axis significantly overlap. Instead it appears to be the pairwise relationship between the frit (or less dense) components and the sludge (or denser) componentsespecially $\mathrm{Al}$-that dictates phase separation for these waste glass compositions; it is not a strong function of solely the frit loading parameter.

Furthermore, the total alkaline concentration (via the strong base-weak acid effect) appears to drive DWPF waste glasses to be poorly durable (apparently when they are already phase separated because of a low $\mathrm{Al}_{2} \mathrm{O}_{3}$ concentration) [8]. Historic information indicates that poorly durable glasses can be found that possess frit loadings down to $66.24 \%$ (or well below the lower limit of $70 \%$ ); however, none of these poorly durable glasses have $\mathrm{Al}_{2} \mathrm{O}_{3}$ concentrations greater than $4 \%$ in glass. To further confirm these assertions, composition and durability measurements were made by the SRTC Mobile Laboratory on seven glasses from a designed series used to examine the effect of composition on liquidus temperature for expected DWPF compositions [16]. All these glasses had $S_{f}$ values below the limit of $70 \%$. The normalized boron releases for these glasses are plotted as functions of the appropriate composition terms in Figure 4. The $S_{\mathrm{f}}$ values for the seven glasses and those data used to generate the current durability model [2,3] are also provided. There appears to be no fundamental relationship between either phase separation or durability and solely the frit loading parameter.

As illustrated in Figure 4, durability appears to increase as the frit loading parameter decreases for these seven glasses. Furthermore, the leach responses of all seven glasses are acceptable when compared to EA glass; only the $\mathrm{SG} 47$ glass, which has relatively low $\mathrm{Al}_{2} \mathrm{O}_{3}$ (i.e., $2.67 \%$ ) and high $\Sigma \mathrm{R}_{2} \mathrm{O}$ (i.e., $18.43 \%$ ) concentrations, has a leach response that even approaches that of EA glass (which could be due to the strong base-weak acid effect). This does not mean that none of these glasses are phase separated (as SG47 may well be). These results indicate that none of the leach responses for these seven glasses are poorly behaved; such behavior is a strong indication of amorphous phase separation or, perhaps, lack of structural integrity. Thus the best information available indicates that there appears to be no fundamental relationship between solely the frit loading parameter and the tendency for an expected DWPF glass to either phase separate or be poorly durable. Thus even though the frits used in DWPF are phase separated and the frit loading parameter provides an indication of how much frit is in a glass, the tendency for a DWPF waste glass to phase separate or be insufficiently resistant to leaching appears to be strong functions of constituent $\mathrm{Al}_{2} \mathrm{O}_{3}$ and $\Sigma \mathrm{R}_{2} \mathrm{O}$ concentrations -not solely the frit loading parameter. Therefore, relaxation of the lower frit loading constraint is warranted because there appears to be no unreasonable chance of the glasses in question exhibiting unexpected phase separation or leaching behavior due solely to decreased frit loading (i.e., below $70 \%$ ). 
WRSC-RP-99-00355, Rev. 0

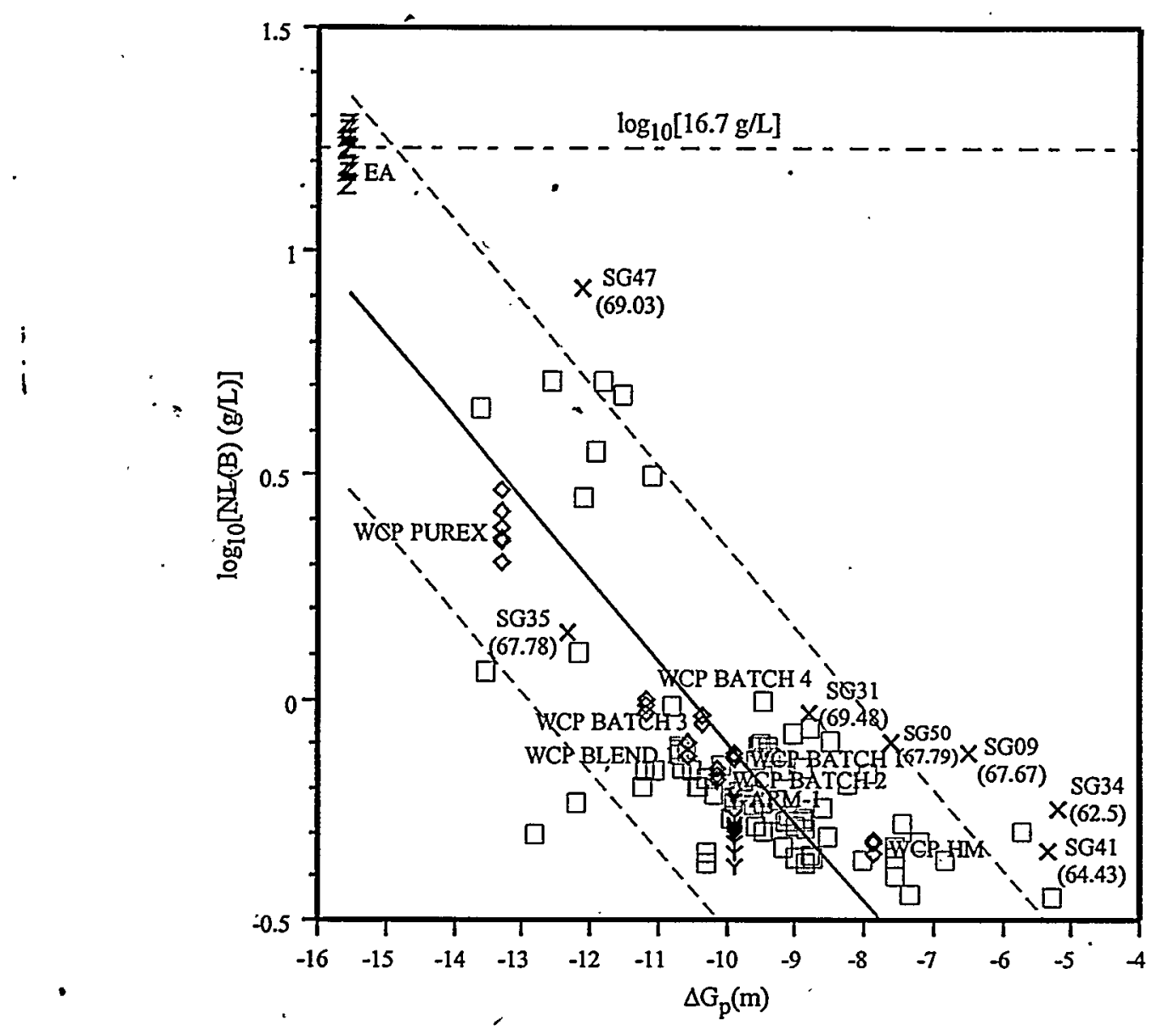

Figure 4. Boron durability, $\log _{10}[\mathrm{NL}(\mathrm{B})(\mathrm{g} / \mathrm{L})]$, versus composition for seven liquidus temperature study glasses, $S G x x,[16]$ exhibiting low frit loading (i.e., $S_{\mathrm{f}}<70 \%$ ). Model data are shown (in gray) and computed $\mathrm{S}_{\mathrm{f}}$ values are provided in parentheses for the SGxx glasses. The limit taken as the average of the measured boron results, or $\log _{10}[16.7(\mathrm{~g} / \mathrm{L})]=1.22$ is also provided for reference.

As a matter of fact, the current state of knowledge concerning DWPF glass chemistry indicates that it is when the total oxide contribution from sludge in a glass is relatively high (and thus frit loading is corresponding low for sludge-only glasses) that the tendency for a glass to phase separate is also relatively low [2]: Therefore, even if the frit loading parameter has a more profound impact on phase separation (and/or durability) than suspected, those DWPF glasses that violate the lower frit loading constraint appear to be unlikely candidates for amorphous phase separation. As suggested by Figure 4, this agrees with historic evidence indicating that DWPF waste glasses may be more likely to phase separate as the frit proportion increases; however, the advent of phase separation in DWPF glasses appears to be a much stronger function of the effect that increasing frit loading has on the $\mathrm{Al}_{2} \mathrm{O}_{3}$ concentration [8]. Thus based upon the current state of knowledge concerning DWPF waste glasses, the risk of having any anticipated DWPF waste glass with a frit loading less than $70 \%$ exhibit amorphous phase separation (or unacceptable durability) appears to be very low as long as the $\mathrm{Al}_{2} \mathrm{O}_{3}$ concentration is greater than $4 \mathrm{wt} \%$ in glass.

However, the drawing of this conclusion is just an intermediate step in the on-going effort to reevaluate the constraints (i.e., frit loading, $\mathrm{Al}_{2} \mathrm{O}_{3}, \Sigma \mathrm{R}_{2} \mathrm{O}$, and homogeneity) associated with durability prediction for DWPF control. Additional work is planned that includes examining the measurements from glasses obtained since DWPF start-up; many are uranium-bearing glasses obtained from sludge-only operation (whereas all but one of the glasses considered for model develop were fabricated from simulated sludge feeds without uranium). Designed experiments are also planned to generate those glasses needed to complement existing data so that all models will be based upon well designed data. However, as discussed in this report, any changes made to the 
WRSC-RP-99-00355, Rev. 0

manner in which durability is predicted for DWPF control must be made in such a way as to maintain rigorous defensibility.

Finally, even if the lower frit loading constraint is omitted, the imposition of the current liquidus temperature constraint [14] will tend to prevent the actual frit loading of any expected DWPF glass from being significantly below the lower limit of 70\% [9]. Therefore, the glasses produced in this manner cannot be far below the minimum considered for development of the homogeneity constraint-which was the primary motivation for defining the frit loading constraints [14]. It appears as though relaxation of the measurement requirement onor even omission of - the lower frit loading constraint will involve minimal risk for DWPF product control. This is especially true since lowering the frit loading is likely the wrong direction to promote amorphous phase separation (and thus poor durability predictability) based upon the current state of DWPF glass chemistry knowledge. However, these assumptions should be confirmed as part of required designed, variability testing [20] prior to vitrification of any new macrobatch in DWPF. The most significant outcome from this examination of thd lower frit loading constraint is that it appears more likely than ever that it may be possible (via designed experiments) to directly relate durability to composition for DWPF process control without abandoning the first-principles of glass chemistry; such an outcome would obviate the need to impose the constraints related to both phase separation and frit loading for DWPF process control. 
WRSC-RP-99-00355, Rev. 0

\section{CONCLUSIONS AND RECOḾMENDATIONS}

The primary conclusion that can be drawn from this examination of the DWPF process and product constraints is that the lower frit loading constraint can be omitted as long as the true $\mathrm{Al}_{2} \mathrm{O}_{3}$ concentration is greater than $4.43 \mathrm{wt} \%$ in glass and all other process and product constraints are applied as described in pertinent technical baseline documentation $[3,8]$. Based upon glass chemistry knowledge and supported by experimental evidence, there appears to be little risk of unknowingly producing phase separated waste glasses in DWPF-provided that the minimum $\mathrm{Al}_{2} \mathrm{O}_{3}$ limit is increased to $4.43 \mathrm{wt} \%$ in glass (and all other constraints are applied as before $[3,8]$ ).

To summarize, when

i

- the limits on $\mathrm{B}, \mathrm{Li}$, and $\mathrm{Na}$ releases, oxîde conservation, liquidus temperature, melt viscosity, high frit loading, and waste solubilities (including limits on maximum $\mathrm{TiO}_{2}, \mathrm{NaCl}, \mathrm{NaF}, \mathrm{Cr}_{2} \mathrm{O}_{3}, \mathrm{Na}_{2} \mathrm{SO}_{4}$, $\mathrm{Cu}$, and $\mathrm{P}_{2} Q_{5}$ concentrations) are applied as described in pertinent baseline documentation $[3,8]$ and

- the minimum true $\mathrm{Al}_{2} \mathrm{O}_{3}$ concentration is raised to $4.43 \mathrm{wt} \%$ in glass

then

- the lower frit loading constraint can be omitted from the acceptance determination. ${ }^{7}$

Furthermore, the acceptance changes in applying the lower frit loading constraint pertain to all expected DWPF glasses, not just those for DWPF Macrobatch 2. However, it would be prudent in the future to test these assertions for each new macrobatch that will be immobilized in DWPF as part of required variability testing.

7 For Tank 42 Sludge, this implies that the measurement uncertainty requirement for the homogeneity constraint and that the lower frit loading constraint can be omitted. 
WRSC-RP-99-00355, Rev. 0

\section{REFERENCES}

1. Waste Acceptance Product Specifications for Vitrified High-Level Waste Forms, Revision 2, U.S. Department of Energy, Office of Environmental Restoration and Waste Management, Washington, DC (December 1996).

2. Jantzen, C.M, Pickett, J.B., Brown, K.G., Edwards, T.B., and Beam, D.C. "Process/Product Models for the Defense Waste Processing Facility (DWPF): Part I. Predicting Glass Durability from Composition Using a Thermodynamic Hydration Energy Reaction Model (THERMO)," WSRC-TR-93-672, Rev. 1, August 1, 1995.

3. Brown, K.G. and Postles, R.L. "SME Acceptability Determination for DWPF Process Control," WSRCTR-95-0364, Rev. 3, February 21, 1996.

4. Paul, A. Chemistry of Glasses, Chapman \& Hall, London, 293pp. (1982).

5. Chick, L.A., McVay, G.L., Mellinger, G.B., and Roberts, F.P. "Annual Report on the Development and Characterization of Solidified Forms for Nuclear Wastes, 1979" U.S. DOE Report PNL-3465, Battelle Pacific Northwest Laboratory (December, 1980).

6. Jantzen, C. M., Brown, K.G., Pickett, J.B., and Edwards, T.B. "Impact of Phase Separation on Waste Glass Durability," WSRC-MS-99-00333, Rev. 0, April 1999.

7. Brown, K.G. and Edwards, T.B. "Definition of the DWPF Homogeneity Constraint," WSRC-TR-95-0060, January 31, 1995.

8. Edwards, T.B. and Brown, K.G. "Evaluating the Glasses Batched for the Tank 42 Variability Study," SRT-SCS-98-0017, May 11, 1998.

9. Brown, K.G. "Mathematical Examination of the DWPF Low Frit Loading Constraint," Draft of SRTCPCC-99-0004, April 12, 1999.

10. Lambert, D.P. and Boley, C.S. "Tank 42 Sludge-Only Process Development for the Defense Waste Processing Facility (DWPF),” WSRC-RP-98-00149, Rev. 1, September 2, 1998.

11. Jantzen, C.M. "Verification of Glass Composition and Strategy for SGM and DWPF Glass Composition Determination," USDOE Report DPST-86-708, E. I. du Pont de Nemours \& Co., Savannah River Laboratory, Aiken, SC, March 1987.

12. Peeler, D.K. "Batch 1 Variability Study Using Twice Washed Tank 51 Sludge (U)," WSRC-RP-95-1045, Revision 1, January 8, 1996.

13. Peeler, D.K. "Batch 1 Variability Study Using Twice Washed Tank 51 Sludge and Frit 200 (U)," WSRCRP-96-200, Revision 0, January 17, 1996.

14. Edwards, T.B. "Development of a Methodology for Comparing PCT Results (U)," WSRC-RP-97-241, Revision 0, April 8, 1997.

15. Hrma, P.R., et al. "Property/Composition Relationships for Hanford High-Level Waste Glasses Melting at 1150C," Volume 2: Chapters 12-16 and Appendices A-K, PNL010359, Vol. 2, UC-721, December 1994.

16. Edwards, T.B. "A Statistically Designed Sampling Plan for Investigating Liquidus Temperature Versus Glass Composition," SRT-SCS-97-0022, 1997.

17. Reeve, C.P. "Statistical Analysis of DWPF Prototypic Tests: SME Feed," SCS-ASG-93-0050, June 14, 1993. 


\section{WRSC-RP-99-00355, Rev. 0}

18. Volf, M.B. Glass Science and Technology, 7: Chemical Approach to Glass, pp. 280-303, Elsevier, Amsterdam, 1984.

19. Edwards, T. B., "Selecting Glass Compositions for the Tank 42 Variability Study (U)," SRT-SCS-98-007, - February 25, 1998. .

20. Marra, S.L., Plodinec, M.J., and Ray, J.W. "DWPF Glass Product Control Program," WSRC-IM-91-116-6, Rev. 2, July 1997. Also, see Plodinec, M.J., Brown, K.G., Marra, S.L., Jantzen, C.M., and Edwards, T.B. "Technical Basis for DWPF Glass Product Control Program," WSRC-IM-91-116-5, Rev. 1, December ; 1995. i 
WSRC-RP-99-00355

Revision 0

\section{DISTRIBUTION:}

L. M. Papouchado, 773-A

E. W. Holtzscheiter, 773-A

C. R. Goetzman, 773-A

S. L. Marra, 704-T

L. F. Landon, 704-1T

D. A. Crowley, 773-23A

J. R. Harbour, 773-43A

R. C. Tuckfield, 773-42A

C. T. Randall, 773-42A

C. M. Jantzen, 773-A

T. B. Edwards, 773-42A

D. K. Peeler, 773-A

A. D. Cozzi, 773-43A

W. E. Daniel, 704-1T

M. N. Brosee, 704-S

T. J. Lex, 703-H

W. D. Kerley, 704-S

J. F. Ortaldo, 704-S (5)

R. E. Edwards, 704-25S

J. Occhipinti, 704-27S

H. H. Elder, 704-S

J. N. Chen, 704-27S

STI, 703-43A (4) 